\title{
GENETICS OF REPRODUCTION IN THE PIG
}

W.G. HILL

Institute of Animal Genesics, University of Edinburgh, UK

and

A.J. WEBB

A.R.C. Animal Breeding Research Organisation, Edinburgh, UK

\section{Genetic principles}

Reproductive performance depends both on the genotype of the pig and the environment which it encounters. Some aspects of this environment, for example the feeding regime, can be specified; other random factors affecting individual pigs cannot. Similarly, there are genetic differences among breeds and animals of the same breed such that there is both genetic and non-genetic variability between pigs of the same breed under the same management system. For traits of reproduction, such as litter size, and its components, such as ovulation rate and embryonic survival, genetic variability is due to segregation of many genes which have, presumably, different effects on each trait and also exist with different frequencies in the population.

Whatever type of management system, feeding regime and disease control the pig producer adopts, he can still benefit from the best choice of breeds and crosses among them, and from genetic changes within them. Genetic and non-genetic improvement are not alternatives for they can, and should, proceed together. An awareness of genetic differences may also enable the research worker in other disciplines to use them to advantage in his experiments or, at least, not confound genetic and other effects.

Firstly in this chapter some of the evidence on genetic variability in reproductive performance is reviewed and then consideration is given to how it is being used in genetic improvement programmes and how it might be used in the future. Most of the information refers to simple measures such as litter size because data on some aspects, e.g. reproductive performance, are scanty.

It is necessary to distinguish between genetic differences in performance observed among and within identifiable populations. These populations can be different breeds, or lines of the same breeds in different herds, as long as they can be jdentified so that stock can be repeatably drawn from them. For example, breed differences in litter size reflect deviations in the frequency of genes affecting litter size among the populations, and can be utilized by selection between them. However, once this selection is made and populations substituted, the gains are maintained without further cost, 
but cannot be repeated. Variation within a population arises as a consequence of Mendelian segregation and much or all of it is reconstituted each generation, depending on the size of the population and selection intensity (Falconer, 1960a). Therefore, selection can be repeated over many generations and genetic progress made continually. It is not usually possible to get precise estimates of genetic variation within any population and, within the margins of statistical sampling error, estimates tend to be similar for different populations. Thus, although an estimate of variance strictly applies to one population, for example a breed at one particular time, it is customary and often necessary to extrapolate results outside this set.

Similarly, the effects of heterosis between breeds will be considered, as will the converse of inbreeding effects within breeds and their extrapolation to other populations. The primary genetic mechanism used to explain heterosis and inbreeding depression is that of dominance at individual loci, so that the heterozygote is superior to the mean of the corresponding homozygotes. Thus, if the dominant alleles differ in frequency between two breeds, the frequency of heterozygotes and therefore performance will be higher in the cross than the parental average. Similarly inbreeding causes a reduction in heterozygosity and therefore performance. Sheridan (1981) has argued, however, that interaction between effects of genes at different loci is often an important cause of heterosis, but there is not adequate evidence of this in the pig.

Reproductive traits show low values of heritability and high values of inbreeding depression compared with growth and carcass traits, which is a measure of the amount of variation that can be utilized by selection and is typical of all animal species.

\section{Variation among breeds}

\section{DIFFERENCES BETWEEN BREEDS}

Breeds of the world exhibit considerable variation in reproductive performance. For example, litter sizes at birth range from around six in wild breeds up to a reputed 22 in some Chinese breeds. This range is much narrower for breeds used in Western pig production, as shown in Table 26.1 which summarizes results from two recent breed comparisons in Europe and the USA. In Europe the Large White strains consistently appear to wean slightly larger litters than Landrace, although differences in total litter weight at weaning are relatively small. In the Dutch study, the Pietrain and Belgian Landrace breeds, both noted for their stress susceptibility and extreme ham conformation, weaned at least 1.6 pigs less than Dutch Large Whites (Table 26.1). Part of this difference may be explained by the higher frequency of the gene for halothane sensitivity in the two breeds, which may cause a reduction in litter size (Webb, 1981). Differences in litter size between American dam breeds arise from differences in both ovulation rate and embryo survival (Table 26.2).

Direct comparisons of up-to-date samples of European and American breeds in the same environment are scarce. In the Dutch evaluation of American breeds several generations after importation into Europe, litter 
Table 26.1 SUMMARY OF SOME PUBLISHED WITHIN-COUNTRY BREED COMPARISONS OF LITTER PRODUCTIVITYY( ${ }^{(\mathrm{a})}$

\begin{tabular}{|c|c|c|c|c|c|c|c|c|}
\hline \multirow[t]{2}{*}{ Breed } & \multirow{2}{*}{$\begin{array}{l}\text { No. } \\
\text { females }\end{array}$} & \multicolumn{3}{|c|}{ Ai birth } & \multicolumn{4}{|c|}{ At weaning } \\
\hline & & $\begin{array}{l}\text { Litter } \\
\text { size }\end{array}$ & $\begin{array}{l}\text { Piglet } \\
\text { weight } \\
(\mathrm{kg})\end{array}$ & $\begin{array}{l}\text { Litter } \\
\text { weight } \\
(\mathrm{kg})\end{array}$ & $\begin{array}{l}\text { Litter } \\
\text { size }\end{array}$ & $\begin{array}{l}\text { Mortality } \\
\text { from } \\
\text { birth } \\
(\%)\end{array}$ & $\begin{array}{l}\text { Piglet } \\
\text { weight } \\
(\mathrm{kg})\end{array}$ & $\begin{array}{l}\text { Litter } \\
\text { weight } \\
(\mathrm{kg})\end{array}$ \\
\hline \multicolumn{9}{|c|}{ (1) Holland, weaning 49 days $^{(b)}$} \\
\hline Dutch Large White & 118 & 9.9 & 1.41 & 13.9 & 8.4 & 15 & 14.5 & 121.8 \\
\hline Dutch Landrace & 122 & 9.4 & 1.54 & 14.5 & 8.1 & 14 & 14.3 & 135.0 \\
\hline Belgian Landrace & 124 & 7.6 & 1.44 & 10.9 & 6.2 & 18 & 13.2 & 81.8 \\
\hline Pietrain & 98 & 8.5 & 1.34 & 11.4 & 6.8 & 20 & 12.2 & 103.7 \\
\hline American Duroc & 109 & 9.8 & 1.51 & 14.7 & 8.6 & 12 & 13.3 & 114.0 \\
\hline \multicolumn{9}{|c|}{ (2) Oklahoma, USA, weaning 21 days $^{(\mathbf{b})}$} \\
\hline American Duroc & 55 & 8.9 & 1.30 & 11.4 & 5.6 & 37. & 4.5 & 25.3 \\
\hline American Hampshire & 56 & 8.4 & 1.24 & 10.2 & 5.4 & 36 & 5.0 & 26.7 \\
\hline American Yorkshire & 50 & 10.2 & 1.08 & 10.7 & 7.7 & 25 & 4.7 & 35.4 \\
\hline
\end{tabular}

(o)References: (1) Brascamp, Cop and Buiting (1979); (2) Young, Johnson and Omtvedt (1976)

(b) (1) Average of parities 1-4; (2) all parties adjusted to gitt basis

size at weaning in the Duroc was comparable to that of the Large White, but for the Hampshire it was intermediate between the Large White and Pietrain. Mortality from birth to weaning in the Duroc and Hampshire was three times higher in the American than in the Dutch study, and it is not clear how far this results from management differences between the two countries. However, in a cross-fostering experiment between American Hampshires and British Saddlebacks (King, 1975) the lower pre-weaning

Table 26.2 DIFFERENCES IN LITTER PRODUCTIVITY BETWEEN DUROC AND YORKSHIRE (D-Y) AND HAMPSHIRE AND YORKSHIRE (H-Y) BREEDS WHEN USED AS SIRES AND DAMS IN THE OKLAHOMA CROSSBREEDING EXPERIMENT

\begin{tabular}{|c|c|c|c|c|}
\hline \multirow[t]{2}{*}{$\overline{\text { Trait }}$} & \multicolumn{2}{|c|}{ Dam breeds } & \multicolumn{2}{|c|}{ Sire breeds } \\
\hline & $D-Y$ & $H-Y$ & $D-Y$ & $H-Y$ \\
\hline $\begin{array}{l}30 \text { days after mating }(n=212)^{(\mathbf{a})} \\
\text { No. corpora lutea } \\
\text { No. live embryos } \\
\text { Corpora lutea/live embryos }(\%)\end{array}$ & $\begin{array}{r}0.2 \\
-0.2 \\
-3.2\end{array}$ & $\begin{array}{l}-1.5^{*} \\
-2.2^{* *} \\
-7.1\end{array}$ & $\begin{array}{l}\overline{0.0} \\
0.8\end{array}$ & $\begin{array}{l}- \\
-0.1 \\
-2.7\end{array}$ \\
\hline $\begin{array}{l}\text { At birth }(n=450) \\
\text { Litter size } \\
\text { Average piglet weight }(\mathrm{kg}) \\
\text { Litter weight }(\mathrm{kg})\end{array}$ & $\begin{array}{c}-0.8^{*} \\
0.24^{* *} \\
1.4^{* *}\end{array}$ & $\begin{array}{l}-2.0^{* *} \\
0.22 * * \\
-0.6\end{array}$ & $\begin{array}{r}-0.5 \\
0.0 \\
-0.7\end{array}$ & $\begin{array}{r}-0.7^{*} \\
0.0 \\
-0.7\end{array}$ \\
\hline $\begin{array}{l}42 \text { days after birth }(n=437) \\
\text { Litter size } \\
\text { Survival from birth }(\%) \\
\text { Average piglet weight }(\mathrm{kg}) \\
\text { Litter weight }(\mathrm{kg})\end{array}$ & $\begin{array}{l}-1.2^{* *} \\
-6.5^{*} \\
-0.03 \\
-11.0^{* *}\end{array}$ & $\begin{array}{l}-1.4^{* *} \\
-0.5 \\
0.18 \\
-11.8^{* *}\end{array}$ & $\begin{array}{l}-0.6^{*} \\
-4.8 \\
-0.03 \\
-7.1^{*}\end{array}$ & $\begin{array}{l}-1.2^{* *} \\
-9.0^{* *} \\
-0.06 \\
-12.5^{* *}\end{array}$ \\
\hline
\end{tabular}

From Young, Johnson and Omtvedt (1976)

('Total number of females in comparison

$\cdot P<0.05$

$\because P<0.01$ 
growth rate of Hampshire piglets could not be improved when nursed by Saddleback dams with greater milk production.

The effect of the breed of boar, other than through heterosis (see following section), on the litter productivity of the dam to which he is mated, is less clear. In the Oklahoma experiment (Table 26.2), sire breed significantly affected litter sizes at birth and weaning, as well as piglet survival and total 49-day litter weight. Within Large White strains, sires have been shown to influence significantly the litter sizes of their mates (Legault, 1970; Strang, 1970), but the proportion of variation due to sires amounted to less than $1 \%$ of the total. Martin and Dziuk (1977) also claimed to demonstrate differences between and within breeds in the conception rates and litter sizes of individual Duroc and Yorkshire boars. Although significant breed of sire effects may exist, it seems unlikely that they will be of major economic importance.

\section{CROSSBREEDING AND HETEROSIS}

Crossbreeding is used to bring together the desirable characteristics from two or more breeds, and to exploit hybrid vigour or heterosis. Heterosis may be defined as the amount by which the performance of the offspring exceeds the mean of its parents. As the parental breeds become more genetically distinct giving a higher level of heterozygosity in the cross, the amount of heterosis is expected to increase. In most circumstances heterosis will only be economically useful if the progeny outperform the better of the two parental breeds.

In pigs useful heterosis can be demonstrated in the genotypes of both the crossbred dam and her crossbred progeny. Published estimates of heterosis have been comprehensively reviewed by Sellier (1976), and are reproduced in Table 26.3. For litter size at weaning, heterosis estimates for the dam and her progeny amount to $11 \%$ and $6 \%$ respectively, giving a total of $17 \%$ or 1.3 pigs weaned per litter. For litter weight at weaning the total advantage from crossbreeding is $22 \%$. These may slightly overestimate the benefits of crossbreeding in Europe for the figures include American studies in which average litter sizes and environmental conditions may be poorer. Nevertheless heterosis in litter productivity has been the main justification for commercial crossbreeding in pigs for the last 10-15 years. It seems likely that heterosis may also be expressed in age at sexual maturity and conception rate in maiden gilts (e.g. Hutchens et al., 1978), but these effects may result partly from the improved growth rate of crossbreds.

The value of crossbreeding in the male is less well established. Heterosis might be expected in fitness-related traits. For example, Neely, Johnson and Robison (1980) demonstrated 34\% heterosis in total number of sperm, but this fell to $14 \%$ after adjustment for the greater body weight of crossbreds. Other studies in US and British breeds (Wilson, Johnson and Wetteman, 1977; Lishman et al., 1975) have shown no clear advantage for crossbred boars on litter productivity. In a British experiment, $F_{1}$ Pietrain $\times$ Hampshire boars increased the litter size of their mates by 0.78 pigs at birth when compared with other types of boars, mainly Large White. The 


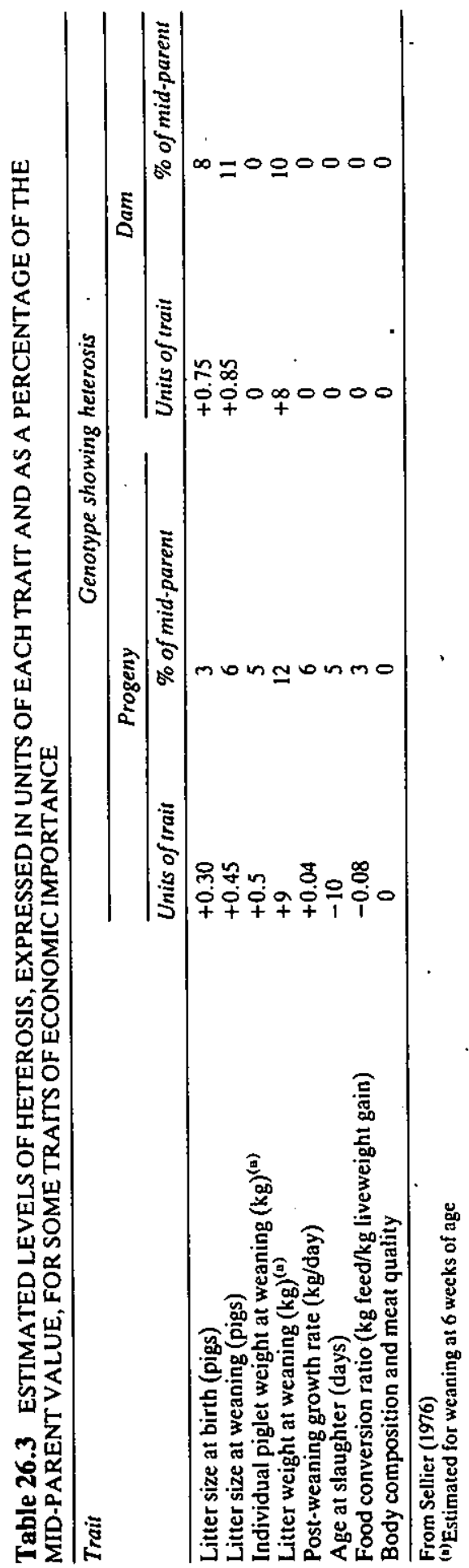


authors (King and Thorpe, 1973) speculated that the Pietrain $\times$ Hampshire advantage could stem from improved mating behaviour under the particular conditions of paddock mating adopted, and might not be detected with hand-mating systems. In future experiments, crossbred boars need to be evaluated under the exact conditions in which they would be used commercially.

In general the performance of a particular cross may be adequately predicted from the mean of its parental breeds together with published estimates of heterosis. For example, recent trials in Holland have shown higher litter sizes at weaning for Dutch Landrace $\times$ Duroc females than Dutch Landrace $\times$ Dutch Large White (Brascamp and Buiting, 1980), and this might have been predicted from the purebred litter sizes in Table 26.1. As in the case of the Pietrain $\times$ Hampshire boars, there will be exceptions. A further complication could be the existence of differences between reciprocal crosses of the form $A O^{\prime \prime} \times B$ or $B \sigma^{\prime \prime} \times A q$, arising mainly from maternal effects of the dam breed. The Oklahoma crossbreeding experiment showed significant reciprocal differences for Duroc $\times$ Yorkshire crosses in piglet weights at birth and 21 days, but not in litter size (Johnson, Omtvedt and Walters, 1978).

\section{SYSTEMS OF CROSSBREEDING}

A variety of different systems of crossbreeding can be used to produce different commercial end products. The systems differ in the amounts of heterosis expressed, and some of the most common are listed in Table 26.4. The systems may be divided into two categories: continuous and discontinuous. In discontinuous systems the crossbred end product is slaughtered, and replacement male and female breeding stock must be specially bred on the farm or purchased from outside. In continuous systems replacement females are selected from the slaughter generation, and only

Table 26.4 EXPECTED LEVELS OF HETEROSIS IN GENOTYPES OF PARENTS AND OFFSPRING FROM DIFFERENT CROSSING SYSTEMS (EXPRESSED AS PERCENTAGE OF HETEROSIS IN $F_{1}$ )

\begin{tabular}{|c|c|c|c|c|}
\hline \multirow[t]{2}{*}{ Crossing system } & & \multicolumn{3}{|c|}{ Genotype showing heterosis } \\
\hline & & Maternal & Paternal & Individual \\
\hline \multicolumn{5}{|l|}{ Discontinuous } \\
\hline $\mathbf{F}_{1}$ & $A \sigma^{\top} \times B$ 우 & 0 & 0 & 100 \\
\hline & $(A \times B) \sigma^{+} \times(A \times B)$ 웅 & 100 & 100 & 50 \\
\hline Backeross & $A \sigma \times(A \times B) q$ & 100 & 0 & 50 \\
\hline 3-breed cross & $C \sigma^{\circ} \times(A \times B)$ Q & 100 & 0 & 100 \\
\hline $\begin{array}{l}\text { 4-breed cross } \\
\text { Continuous }^{(\mathbf{b}}\end{array}$ & $(C \times D) \sigma^{\prime} \times(A \times B) q$ & 100 & 100 & 100 \\
\hline 2-breed rotation & $\ldots(B \times(A \times(B \times(A \times B)$ & 67 & 0 & 67 \\
\hline 3-breed rotation & $\ldots(B \times(A \times(C \times(A \times B)$ & 86 & 0 & 86 \\
\hline 4-breed rotation & $\ldots(A \times(D \times(C \times(A \times B)$ & 94 & 0 & 94 \\
\hline \multicolumn{5}{|c|}{ Purebred male and 2-breed rotation } \\
\hline female: & $C \sigma^{\prime} \times(\ldots(A \times(B \times(A \times B)) q$ & 67 & 0 & 100 \\
\hline
\end{tabular}

(o) Heterosis levels shown are those attained at equilibrium, roughly five generations after starting the rotation crosses 
males are brought in. Continuous systems therefore offer less disease risk from incoming stock, lower replacement costs, but also less of the important maternal heterosis than discontinuous systems.

In the UK with only two main breed types, Large White and Landrace, the backcrossing system predominates, with breeding companies offering 'package deals' of replacement $F_{1}$ gilts and purebred boars. In recent years the loss of $50 \%$ heterosis in individual pig performance from a backcross (Table 26.4) has not been thought sufficient to justify the widespread use of a third 'sire' breed, with possibly inferior conversion of food to lean. Rotation crossing schemes are commonplace in the USA.

As the differences in litter productivity between crossing systems are likely to be small, very large numbers of litters are required to test theoretical expectations in practice. In 1968 a long-term experiment was started at ABRO (King, 1978) to compare the litter productivity of $F_{1}$ and $F_{2}$ Large White $\times$ Landrace females with 2- and 3-breed rotation crosses involving Large White, Landrace and Saddleback. Both types of rotation cross were conducted using either outbred boars or boars which were of inbreeding at least that of two consecutive brother $\times$ sister matings. The preliminary results (Table 26.5 ) show the expected advantage in litter size

Table 26.5 LITTER PERFORMANCE OF VARIOUS CROSSBREDS EXPRESSED AS DEVIATIONS FROM LARGE WHITE GILTS

\begin{tabular}{|c|c|c|c|c|c|}
\hline \multirow[t]{2}{*}{ Type of cross } & \multicolumn{2}{|c|}{ No. of litters } & \multirow{2}{*}{$\begin{array}{l}\text { Average } \\
\text { no. born } \\
\text { alive }\end{array}$} & \multirow{2}{*}{$\begin{array}{l}\text { Average } \\
\text { no. weaned } \\
\text { perlitter }\end{array}$} & \multirow{2}{*}{$\begin{array}{l}\text { A verage } \\
\text { weaning } \\
\text { weight } \\
(\mathrm{kg})\end{array}$} \\
\hline & Birth & Weaning $^{(\mathrm{a})}$ & & & \\
\hline Purebred Large White (absolute values) & 97 & 90 & 9.36 & 7.48 & 13.6 \\
\hline$F_{1}$ generation & 118 & 114 & 0.84 & 1.01 & 0.4 \\
\hline$F_{2}$ generation & 78 & 76 & 0.28 & 0.87 & 0.0 \\
\hline 2-breed rotation with outbred boars & 88 & 80 & -0.03 & 0.53 & 0.5 \\
\hline 2-breed rotation with inbred boars & 124 & 121 & 0.94 & 1.32 & -0.1 \\
\hline 3-breed rotation with outbred boars & 91 & 88 & 0.68 & 0.99 & 0.9 \\
\hline 3-breed rotation with inbred boars & 92 & 87 & 1.08 & 1.19 & 0.5 \\
\hline $\begin{array}{l}\text { Average standard error of deviation } \\
\text { of cross from Large White }\end{array}$ & - & - & 0.42 & 0.36 & 0.3 \\
\hline
\end{tabular}

From King (1978)

(a) Litters were weaned at 50 days of age

weaned for the $F_{1}$ over purebred Large White, although heterosis and breed effects are confounded. There is the expected reduction in the $F_{2}$ and 2-breed rotation. Prior inbreeding of the boars used in both rotations appears to give a boost in litter size, perhaps due to natural selection during inbreeding, but this deserves further investigation.

A theoretical full economic comparison of crossing systems of the American breeds has been undertaken using actual results from the Oklahoma experiment (Wilson and Johnson, 1979). Productivity was expressed as the number of pigs produced from each system per 10000 total females farrowing either as purebreds or crossbreds. Numbers of pigs were adjusted to compensate for differences in production costs and carcass values arising from differences in growth rate, feed efficiency and backfat. The results are summarized in Figure 26.1. The most productive crossing system was a backcross of a Yorkshire boar to an $F_{1}$ Duroc $x$ 


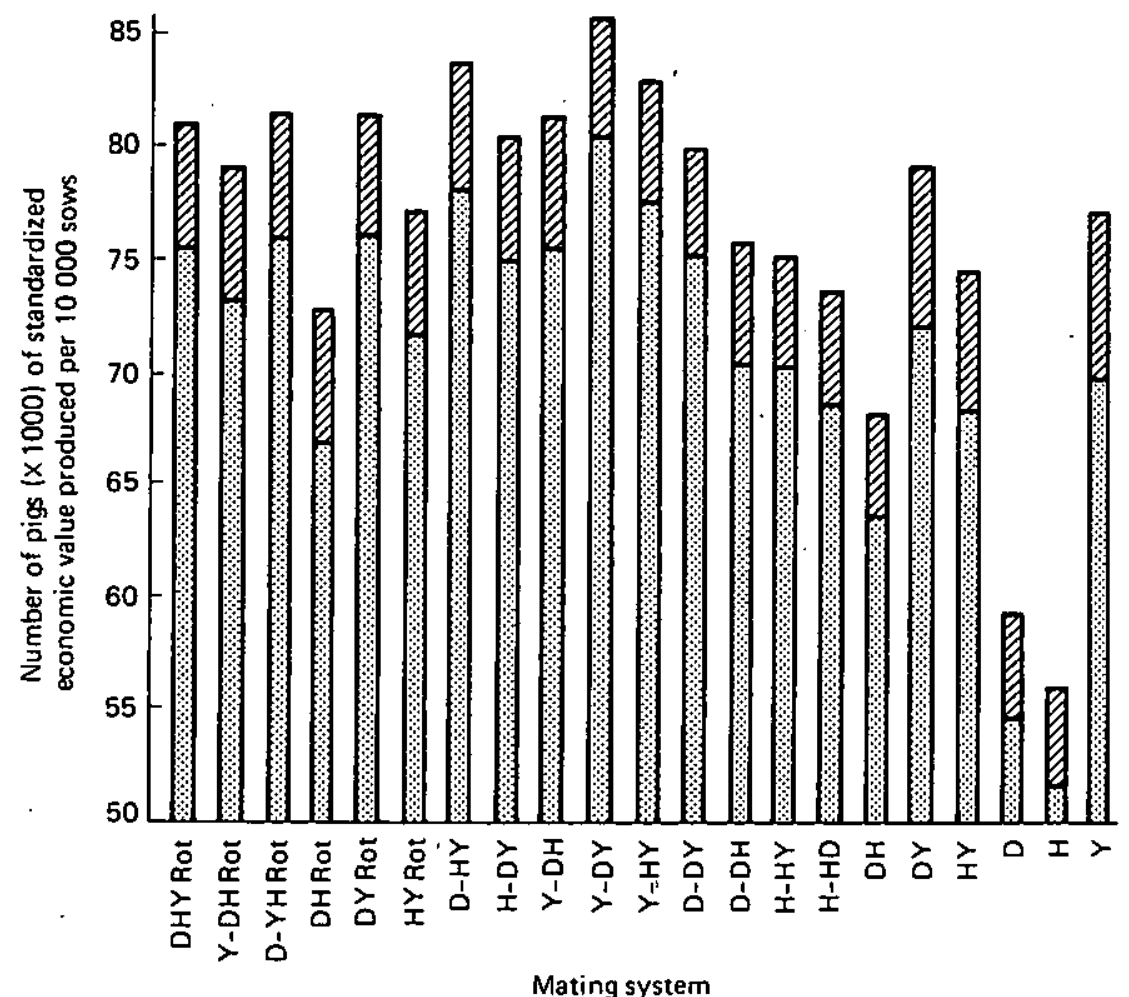

Figure 26.1 Predicted total number of pigs produced per 10000 sows from different crossing systems involving Duroc (D), Hampshire (H) and Yorkshire (Y) breeds. DHY Rot $=3$-breed rotation of $\mathrm{D}, \mathrm{H}$ and $\mathrm{Y} ; \mathrm{Y}-\mathrm{DH} \mathrm{Rot}=\mathrm{Y}$ terminal sire mated to 2-breed rotation dam containing $\mathrm{D}$ and $\mathrm{H} ; \mathrm{Y}-\mathrm{DH}=\mathrm{Y}$ terminal sire mated to $\mathrm{F}_{1} \mathrm{D} \times \mathrm{H}$ dam; $\mathrm{DH}=\mathrm{F}_{1}$ cross of $\mathrm{D}$

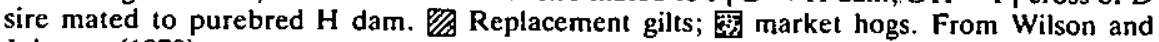
Johnson (1979)

Yorkshire female (Y-DY), and the least was the purebred Hampshire (H) with $34 \%$ lower productivity. Both the 3-breed rotation (DHY Rot) and the best 2-breed rotation (DY) were $3 \%$ less productive than the best 3-breed discontinuous cross (D-HY). The 'winning' backcross (Y-DY) was, however, only $2 \%$ more productive than the $\mathrm{D}-\mathrm{HY}$ discontinuous cross. Another comparison of systems obtained by pooling all published crossbreeding results from the whole of North America led to broadly similar, though not identical, conclusions (Quintana, 1979).

\section{Variation within populations}

\section{REPEATABILITY AND HERITABILITY}

There have been extensive studies of genetic variability in reproductive traits based on field data and therefore over a range of management schemes (for a review of earlier work see Legault, 1970). As a basis, figures 
for means, standard deviations and coefficients of variation averaged over litters from the extensive study on British Large Whites by Strang (1970) are given in Table 26.6. Notable are the high coefficients of variation, around $25 \%$ for numbers and weights and almost $100 \%$ for mortality, which are much higher than for growth and carcass traits.

Correlations of reproductive rate over successive litters of sows, customarily referred to as repeatabilities, are also shown in Table 26.6 for the

Table 26.6 MEANS, STANDARD DEVIATIONS (SD), COEFFICIENTS OF VARIATION (CV) AND REPEATABILITY OF PERFORMANCE IN SUCCESSIVE LITTERS ( $r$ ) IN BRITISH LARGE WHITE PIGS

\begin{tabular}{lcclc}
\hline Trair & Mean $^{(\mathrm{a})}$ & $S D^{(\mathrm{a})}$ & $C V(\%)^{(\mathrm{u})}$ & $r(\%)^{(\mathrm{b})}$ \\
\hline Number of pigs alive & & & & \\
$\quad$ Birth & 10.9 & 2.8 & 26 & 15 \\
3 weeks & 9.0 & 2.3 & 26 & 14 \\
8 weeks & 8.8 & 2.3 & 26 & 14 \\
Percentage mortality & & & & 10 \\
$\quad$ 0-3 weeks & 16.5 & 15.6 & 95 & 12 \\
0-8 weeks & 18.4 & 16.2 & 88 & 17 \\
Average piglet weight (kg) & & & & 4 \\
3 weeks & 6.0 & 1.1 & 18 & 15 \\
8 weeks & 16.8 & 4.6 & 27 & 4 \\
Litter weight (kg) & & & & 28 \\
3 weeks & 53 & 15 & 25 & \\
8 weeks & 144 & 50 & 25 & \\
\hline
\end{tabular}

(a) From Strang (1970)

(b) From Strang and King (1970)

same data set (Strang and King, 1970). These figures are typical of others in the literature, which are fairly consistent (summarized by Strang and Smith, 1979), and around $15 \%$ for litter size. By weaning, piglet and litter weights have a lower repeatability, presumably through the influence of different sires. Providing there is no negative environmental correlation of performance in successive farrowings, the repeatability can be regarded as an upper limit to heritability of traits dependent solely on the sow's genotype, because the correlation includes non-additive genetic and environmental components common to all litters.

Despite the extensive data sets, several involving over 30000 litters, published estimates of heritability (the ratio of additive, i.e. transmissable, genetic variance to total or phenotypic variance) differ markedly (Table 26.7). Some of these differences may reflect real genetic differences among the populations analysed, but many probably reflect sampling error and the difficulties of correcting for identifiable sources of environmental variability, such as herds and seasons.

An effect of the size of the litter in which the pig is born on her own subsequent productivity has been found in two studies. Nelson and Robison (1976) reared piglets from 24 hours in litters of 6 or 14, and observed differences in their subsequent first litters in favour of those reared in the smaller litters of 0.88 in numbers born, 1.18 in numbers born alive and $0.70 \mathrm{~kg}$ in litter weight at birth, although all effects were non-significant $(P>0.05)$. Similarly, Rutledge (1980) compared the productivity of pigs reared in reduced litters of mean size 5.8 with those reared 


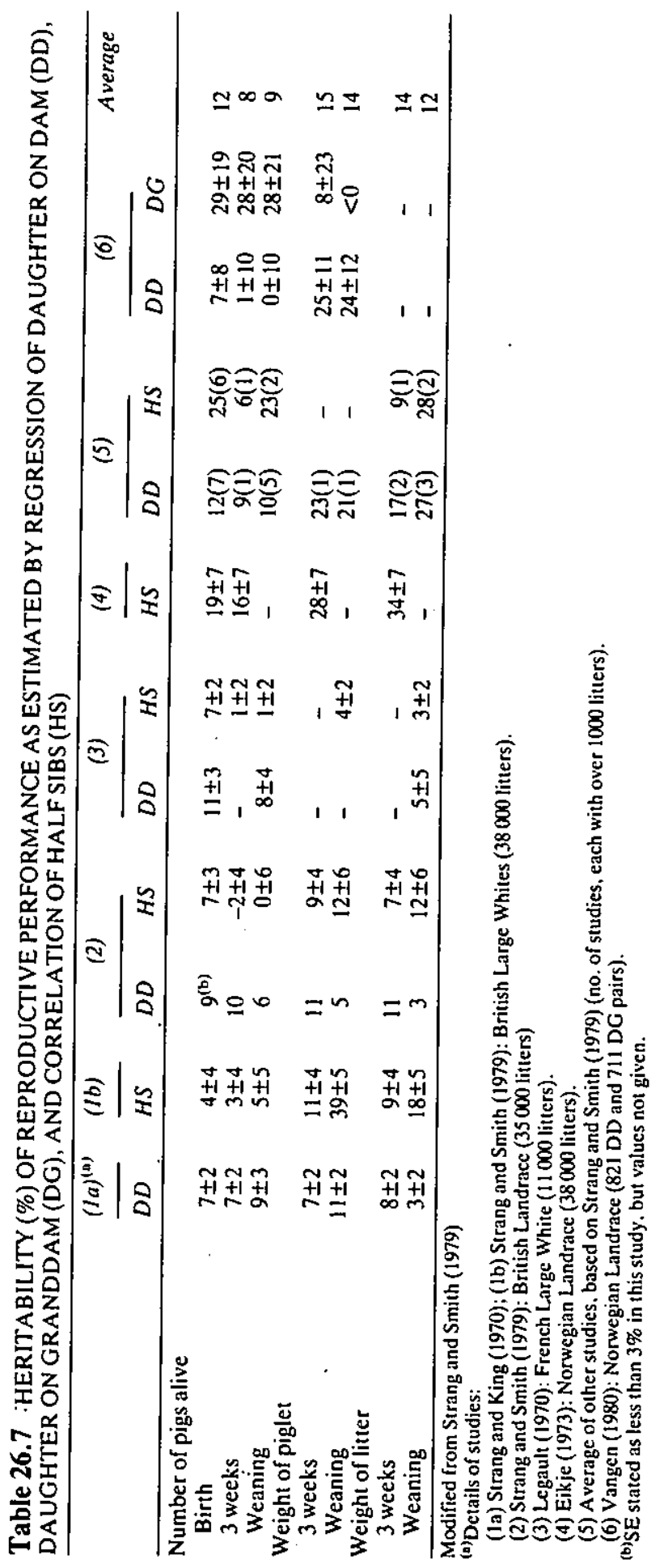


in unaltered litters of mean size 10.1, and found an increase in the former of 0.81 in size of their first litter, although the estimate is confounded with selection effects.

A negative environmental correlation between the litter size of the dam and her progeny has also been demonstrated for mice (Falconer, 1960b). Presumably the effects are mediated through the influence of litter size on subsequent bodyweight. In view of the negative environmental correlation, Revelle and Robison (1973) have argued that heritability estimates from the regression of daughter on dam are biased downwards, and are likely to be smaller than those calculated from the correlation of half-sibs. The two kinds of heritability estimates are shown in Table 26.7 and although the estimates are erratic, there seems to be no consistent difference between them. Vangen (1980) recently obtained higher heritabilities of litter size from daughter-granddam than daughter-dam regressions, although with large standard errors, and argued that this resulted from the negative maternal correlation between generations.

A typical figure for heritability is about $10 \%$ for litter size with somewhat higher values for litter weights. Higher values would not, however, be consistent with the repeatability estimates shown in Table 26.6. In contrast, typically quoted figures for the heritability of growth rate and feed conversion ratio are about $30 \%$, and for fat depths and other carcass quality measures they are about $50 \%$.

The heritability of the size of individual litters appears to decline somewhat with increasing parity in Strang and King (1970) and Strang and Smith (1979)'s data, presumably as environmental effects accumulate. Vangen (1980) found the reverse in a smalter data set and argued that negative dam-daughter environmental covariances were declining. The heritability of mean litter size, however, increases as more records are included.

Different measures of reproduction rate in a single litter are quite highly correlated both genetically and phenotypically, not surprisingly since they are usually part-whole relationships. For example, estimates of the genetic correlation between numbers born alive and numbers at eight weeks are 0.9 by Strang and King (1970) and 0.7 by Legault (1970), and those between number at eight weeks and litter weight at the same age are 0.3 and 1.0 , respectively.

\section{SELECTION EXPERIMENTS}

Selection experiments can be practised in a population both to estimate genetic variability within it and to assess the short-term and long-term responses likely in commercial practice. Little experimental work has been done on selection for litter size in pigs; much more has been done in mice which seems a relevant model because of their litter size has a similar mean and variability.

\section{Pigs}

A selection experiment for increased litter size has been conducted in France. Although the response after the first five generations was greater 


\section{2}

\section{Genetics of reproduction in the pig}

than expected at $0.29 \pm 0.45$ piglets/litter, there was no significant total response in numbers born in the first two litters at generation 10 (Ollivier and Bolet, 1981). Rutledge (1980) reported on the first two generations of selection for litter size in two selected lines, one with litter size reduced at birth, the other unaltered (see p.549). There is an indication, as yet inconclusive, of a response in the former.

\section{Mice, as a model for pigs}

There have been several experiments selecting directly for litter size in mice (Falconer, 1960b; Bateman, 1966; Bradford, 1979; Bakker, Wallinga and Politiek, 1976; Joakimsen and Baker, 1977; Eisen, 1978). All showed responses for increased litter size over periods of selection from 11-20 generations, ranging from 1.6-4.6 mice born/litter with a mean of over 3 mice/litter, equivalent to $21-50 \%$ with a mean near $35 \%$ of the initial litter size. The realized heritabilities (i.e. the heritability achieved during selection) ranged from $13-22 \%$ with a mean of $16 \%$. These mice data suggest that responses could be obtained to selection for litter size in pigs, but in view of the rather lower heritability estimates in pigs of about $10 \%$ (Table 26.7), responses of the same rate are unlikely.

\section{INDIRECT SELECTION}

An alternative to selecting on litter size alone is to devote some or all selection effort to traits which are correlated with it. Of these the obvious one is ovulation rate which can be measured, albeit laboriously, by laparoscopy and repeat measurements can be made over successive oestrous cycles before breeding decisions are made. Cunningham et al. (1979) obtained a substantial response from selection on ovulation rate, but almost no response in litter size because all the gains in ovulation rate were wiped out by a corresponding increase in embryo mortality. This same result was obtained with mice by Land and Falconer (1969) in selection for natural ovulation rate. In contrast, selection for litter size in the French experiment, although unsuccessful, appears to have slightly increased ovulation rate by about 1.2 eggs (Ollivier and Bolet, 1981). A more indirect measure proposed by Land (1973) as a correlate of litter size is testis size. This has been selected for in mice, but the correlated response in ovulation rate was not accompanied by a response in litter size (Islam, Hill and Land, 1976). On the other hand, Bradford (1979) was able to demonstrate improvements in both ovulation rate and prenatal survival from long-term selection for litter size in mice.

\section{ASSOCIATION WITH GROWTH TRAITS}

Extensive data are needed to enable estimation of the genetic correlations between reproductive performance and traits of the growing animal. A summary of two analyses available is given in Table 26.8. Although the correlation between measures of reproductive rate and total index score 
Table 26.8 GENETIC CORRELATIONS (\%) BETWEEN TRAITS OF THE GROWING ANIMAL AND REPRODUCTIVE TRAITS (LS = LITTER SIZE AT BIRTH; LW3 AND LW8 = LITTER WEIGHT AT 3 AND 8 WEEKS)

\begin{tabular}{|c|c|c|c|c|c|c|}
\hline \multirow{3}{*}{$\begin{array}{l}\text { Breed } \\
\text { Trait }\end{array}$} & \multicolumn{4}{|c|}{ British $^{(0)}$} & \multirow{2}{*}{\multicolumn{2}{|c|}{$\frac{\text { French }^{(\mathbf{b})}}{\text { Large Whise }}$}} \\
\hline & \multicolumn{2}{|c|}{ Large White } & \multicolumn{2}{|c|}{ Landrace } & & \\
\hline & $L S$ & $L W 3$ & $L S$ & $L W 3$ & $L S$ & LW8 \\
\hline Daily gain & 6 & 13 & 44 & 77 & -8 & 6 \\
\hline Food conv. ratio & -15 & -9 & -21 & -40 & 8 & 9 \\
\hline Killing out \% & -63 & -45 & -49 & -65 & - & - \\
\hline Backfat & -18 & -15 & -36 & -21 & 11 & -11 \\
\hline Hindquarters \% & -41 & -18 & -12 & -20 & - & - \\
\hline Ham and loin \% & - & - & - & - & 2 & 49 \\
\hline Total index points & 1 & -1 & -4 & 2 & - & - \\
\hline
\end{tabular}

(0)Morris (1975): SE's 30\% for Large White, $45 \%$ for Landrace

(b) Legault (1971): SE's not given; correlation of LW8 with ham and loin percentage significant $(P<0.05)$; remainder non-significant

for growth/carcass traits was small in the study of Morris (1975) and for most traits in the study conducted by Legault (1971), there is some indication of a positive correlation between litter size and daily liveweight gain and negative correlations between litter size and killing out percentage (an unfavourable correlation) and between litter size and backfat depth (a favourable correlation). These latter observations accord with the view that genetically fast growing lean pigs at a fixed (slaughter) weight are immature, and tend to have a higher mature body size. There is good evidence from mice, for example, that adult body size and litter size are positively correlated (Falconer, 1973). Lines of pigs selected for high and low fat depths at Beltsville, however, showed very little change in litter size in either of two breeds for either direction of selection (Hetzer and Miller, 1970). In summary, litter and growth traits in pigs seem to be weakly correlated, but the data are not very conclusive.

\section{SINGLE GENES}

The majority of reproductive characters can be assumed to be controlled by a large number of genes each of small effect. However, a small number of associations have been demonstrated between reproductive rate and single loci with two or more segregating alleles. The loci most readily detected in the past have been those controlling the red cell antigens, and polymorphic enzymes which can be distinguished by electrophoresis. The associations with performance can arise either from direct effects from the loci themselves, or from close linkage with other loci or groups of loci with major effects. For example, matings involving heterozygotes for the ' $\mathrm{C}$ ' allele at the serum transferrin locus $\left(\mathrm{T}_{f}{ }^{\mathrm{C}}\right)$ have been shown to reduce litter size at birth by 1.4 pigs, possibly due to linkage with a lethal gene (Imlah, 1970). More recent studies with the halothane test have shown a reduction in litter size of about 1.1 pigs weaned for recessive homozygotes at the halothane locus (HAL ${ }^{n n}$ ) (Webb, 1981). In turn, HAL is closely linked to the loci for serum phosphohexose isomerase (PHI) and the ' $\mathrm{H}$ ' red cell 


\section{4}

antigen system (Andresen, 1979). In the Duroc and Yorkshire breeds, in which the $\mathrm{HAL}^{n}$ allele is assumed to be absent or at a very low frequency, the difference between sires of phenotypes $\mathrm{H}^{a l}$ and $\mathrm{H}^{\prime-}$ in their mate's litter size at weaning averaged 0.9 pigs (Rasmusen and Hagen, 1973). The apparent effect of HAL on litter size could therefore result from linkage with $\mathrm{H}$.

As reviewed recently by Smith and Webb (1980), an association with a single gene may be a potentially useful aid to selection, provided its effects are adequately estimated. Although normal methods of selection will automatically make use of the locus, for a trait such as litter size which has a low heritability and is expressed only in females, a single locus may add significantly to the rate of progress.

\section{EFFECT OF INBREEDING}

Inbreeding is the mating together of individuals more closely related to each other than are members of the same population chosen at random. It is measured as the coefficient of inbreeding, on a scale from 0 to $100 \%$, and is defined as the probability that the two genes at any locus in an individual are identical by descent. Thus, for example a full-sib or offspring $\times$ parent mating results in progeny with an inbreeding coefficient of $25 \%$, and a half-sib mating gives a coefficient of $12.5 \%$. In a closed random mating population the rate of inbreeding, or annual increase in inbreeding coefficient, depends on the number of breeding animals, and will be greater in small populations, particularly if few males are used. Litter size and weight are expressions of both the dam's genotype (e.g. ovulation rate, milk production) and her progeny's genotype (e.g. viability). Since inbred dams can have non-inbred litters and vice versa, the inbreeding effects have to be partitioned into dam and litter components.

The effects of inbreeding on litter productivity are summarized in Table 26.9, updated from Sellier (1970) by including results of Mikami, Fredeen and Sather (1977). These inbreeding effects were computed by assuming a linear relation between performance and inbreeding coefficient, as predicted by simple genetic models. The studies involve relatively low average levels of inbreeding (below 50\%), and at higher levels the effects may be different.

On average, litter size at weaning appears to be reduced by about one third of a pig per $10 \%$ increase in the inbreeding coefficient of the litter, and by one quarter of a pig per $10 \%$ increase in the dam's inbreeding. Individual pig and whole litter weights at weaning are also reduced by

Table 26.9 EFFECTS OF A 10\% INCREASE IN INBREEDING ON LITTER PRODUCTIVITY(a)

\begin{tabular}{llllll}
\hline $\begin{array}{l}\text { Inbred } \\
\text { genotype }\end{array}$ & \multicolumn{2}{c}{ Litter size } & & \multicolumn{2}{c}{ Weight at 56 days $(\mathrm{kg})$} \\
\cline { 2 - 3 } & Born alive & 56 days & & Piglet & Litter \\
\hline Litter & -0.13 & -0.34 & & -0.36 & -5.96 \\
Dam & -0.23 & -0.23 & -0.26 & -3.31 \\
\hline
\end{tabular}

After Sellicr (1970) with additional results from Mikami, Fredeen and Sather (1977)

(') Based on over 13000 litters for cach of litter and dam effects 
inbreeding, with greater reductions for inbreeding of the litter than the dam. In an analysis of 10000 litters in the USA (Bereskin, Shelby and Cox, 1973), survival from birth to weaning was reduced by $1.2 \%$ of piglets per $10 \%$ increase in inbreeding of the litter, and by only $0.1 \%$ per $10 \%$ increase in dam's inbreeding.

Estimated rates of inbreeding in British breeds ranged from $0.35-0.70 \%$ per generation in the early 1960 s, and currently average about $0.52 \%$ per generation or $0.30 \%$ per year (Smith et al., 1978). A similar increase of around $0.50 \%$ per generation has been reported in Danish Landrace from 1934 onwards (Jonsson, 1971), and $0.61 \%$ per generation in the Poland China from 1885 to 1929 (Lush and Anderson, 1939). Other estimated rates in European breeds range from $0.3 \%$ to $0.8 \%$ per generation (Langholz, 1968; Hanset, 1973). A rate of around $0.5 \%$ per generation therefore seems typical for many pig populations, and seems unlikely to lead to a noticeable decline in reproductive performance. Indeed, because natural selection would be opposing the inbreeding effects, it is possible that with low rates of inbreeding the effects are smaller than shown in Table 26.9. The use of crossbreeding eliminates any cumulative inbreeding effects.

In maize the production and subsequent crossing of inbred lines has proved a highly successful method of genetic improvement. In pigs this technique is ruled out by the length of time required to reach high inbreeding coefficients, the loss of selection pressure for growth traits and the loss of lines. For example, of 146 inbred Large White lines started in Britain in the fifties by mating a boar to all his full-sisters, only $18(12 \%)$ survived to inbreeding coefficients of $40 \%$ or more (King, 1967). The main reasons for loss were small litter size or piglet weights at birth and weaning. Losses from genetic defects, such as monorchidism or intersexes, resulting from increased homozygosity of harmful recessive genes occurred in only $6 \%$ of lines.

\section{Genetic improvement}

\section{REPRODUCTION VERSUS GROWTH}

The pig breeder has to effect genetic improvement in the overall efficiency of the pig enterprise from breeding to fattening, and cannot consider reproductive rate alone. Indeed the greater part of the total cost, particularly of food, is incurred by the slaughter animal after weaning. Methods for comparing the economic importance of litter size and growth (these terms are used to imply overall reproductive performance and the overall composite of gain, food efficiency and carcass value) were formalized by Moav (1966) in terms of profit equations. These have been revised using more recent cost and return figures by Clarke and Smith (1979) and their equation for bacon pigs in the UK is:

$$
P=47.6-10.2 Y-240 / X
$$

where $P=$ profit in pence $/ \mathrm{kg}$ liveweight at slaughter, $Y=$ food conversion ratio (food/liveweight gain), and $X=$ number of pigs sold per sow per year. 
This is illustrated as iso-profit contours in Figure 26.2. In these formulae, returns depend on the inverse of litter size, on the basis that the annual sow cost is spread over the $X$ piglets in an integrated operation. These figures do not necessarily apply to any single producer who can, for example, market the additional weaner pig at a price independent of his mean litter size. A breeder, however, has to take an industry-wide view, so the inverse relationship is more relevant, at least in a fixed market.

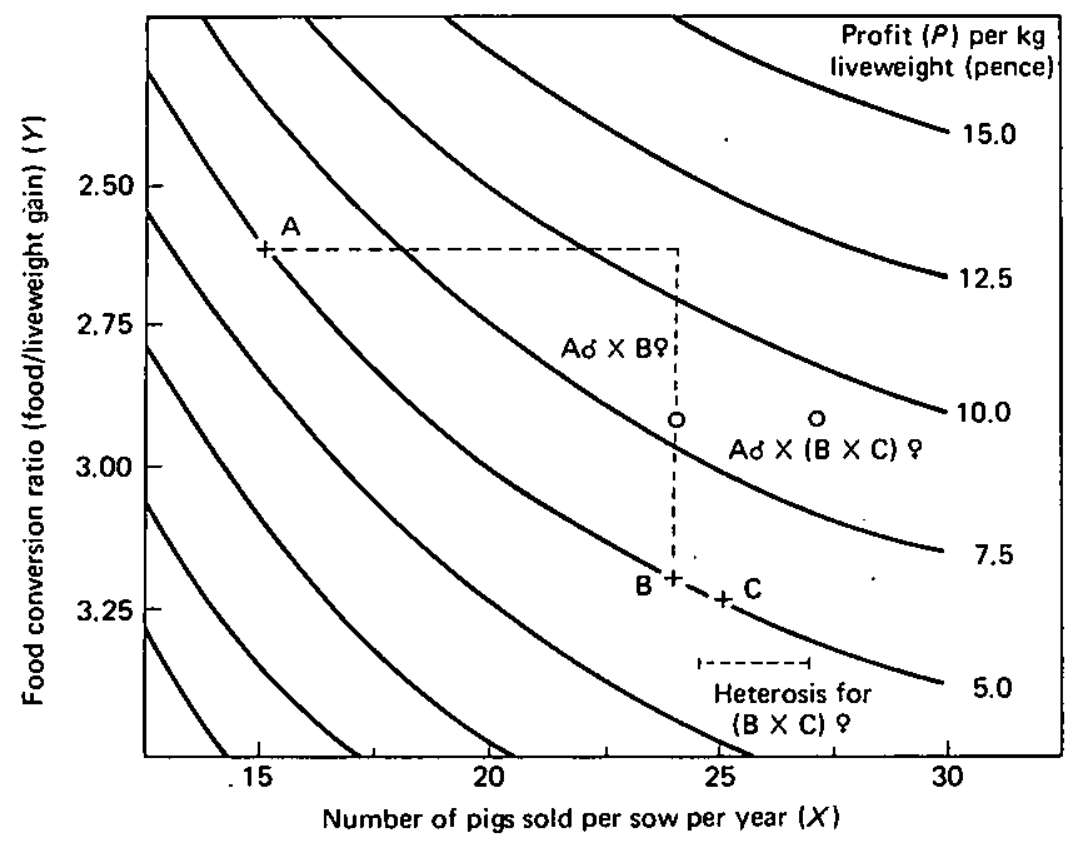

Figure 26.2 Iso-profit contours from production of breeds A, B and C, and their crosses. Profit $(P)$, expressed in pence $/ \mathrm{kg}$ liveweight, is calculated from Equation (1). Based on figures of Clarke and Smith (1979)

The relative advantages of alternative potential purebreds (A, B or C) are illustrated in Figure 26.2 which shows that at commercial levels of 20 pigs/sow/year, little worsening $(0.056)$ in lean tissue feed conversion can be tolerated if a breed B producing $21 \mathrm{pigs} / \mathrm{sow} / \mathrm{year}$ is to be substituted. The figure also illustrates the benefits of crossbreeding lines differing in growth and litter size, using the more prolific breed (B) as the dam, but since the dam breed contributes one half of the genes for growth, it cannot be too inferior for growth rate. Finally, the gains from heterosis in using the crossbred $\mathrm{B} \times \mathrm{C}$ sow are illustrated.

\section{BREED EVALUATION}

In an earlier section the relative merits of different crossing systems were discussed in relation to breed evaluation (see p.546). In principle, breed 
and cross evaluation for reproductive rate and for total economic merit is quite straightforward, but there are major practical problems, particularly for reproductive rate. Litter size is highly variable, so, for example, to obtain a standard error of less than $0.25 \mathrm{pigs} / \mathrm{litter}$ in a breed comparison requires nearly 150 unrelated sows of each breed each having two litters. If related animals are used, the numbers must be higher. Any assessment of lifetime performance would involve further expense and facilities. Furthermore, care must be taken to eliminate any environmental effects at their source on the sows' subsequent performance. This can be avoided if comparisons are required and made through crossbreds by use of semen, but the results cannot be extrapolated to purebred performance because of possible differential heterosis between alternative breed combinations.

It is for reasons such as these that our knowledge of differences in reproductive rate among pig populations in Britain, for example, among commercial breeding companies' stocks is inadequate. Similarly there are no good recent estimates of the amount of heterosis between British Large Whites and Landrace which may have diverged further since the early 1960 s as inbreeding has progressed.

\section{SYNTHETIC LINES}

An alternative to breed replacement or maintenance of a fixed crossing structure is to develop new synthetic breeds. The aim may be to combine the best features of each component breed, but inevitably it must represent close to mean performance for each trait, together with one half of the heterosis (i.e. as for an $F_{2}$, see Table 26.4). The synthetic breed also has a potential benefit in restoring variation if the parental breeds are inbred. Nevertheless the synthetic pig breeds established many years ago in North America have not been very successful, perhaps largely because their foundation populations were too small (Lopez-Fanjul, 1974).

\section{IMPROVEMENT WITHIN BREEDS}

Most pig breeders have devoted little selection effort to reproductive performance in recent years, and have concentrated on performance testing for growth and carcass traits. This largely derives from calculations of responses from alternate selection schemes (Smith, 1964; Moav and Hill, 1966) which showed that the responses in litter size were likely to be slow. This resulted from its low heritability and expression solely in one sex and at later ages than growth characteristics, and consequently monetary returns are small in view of the economic computations illustrated in Figure 26.2. There are increased benefits from developing specialized sire and dam lines in which reproductive performance is ignored in the former and can get doubled weight in the latter. However, using Equation (1), Clarke and Smith (1979) agreed with earlier work in concluding that the extra benefits were small.

The obvious and simplest method of attempting to improve litter size is by selecting replacement stock from among animals born in the largest 
litters. For example, selecting boars from the top $2.5 \%$ of litters and gilts from the top $25 \%$, assuming a heritability of $10 \%$, a phenotypic standard deviation of 2.8 pigs, and a generation interval of one year, a predicted annual rate of progress of 0.25 piglets/litter would result. This theoretical rate can be improved in several ways such as keeping sows for two or more litters and selecting on their total record, and including litter records on full- and half-sisters (i.e. the young pigs' aunts) in a selection index, which can double the predicted rate of improvement. Even so, the economic benefit from selecting on growth and carcass traits alone is likely to be four or more times greater.

A problem is that selection between litters, particularly when it includes records on relatives, leads to much more rapid rates of inbreeding than selection on individual performance. To overcome this, the size of herd in which selection takes place would have to be rather large. Progeny testing programmes are also restricted by inbreeding, but in any event are likely to be less effective than programmes using contemporary relatives' records, since the interval between generations would be longer.

A method of obtaining an initial boost in litter size is to screen the national herd for sows which have proved highly prolific over several litters and bring these together to found a 'hyperprolific' population by mating the sows themselves to the sons of others in the same group. It should, in theory, be feasible to gain about one pig/litter in this way, but the wider the screening net, the lower the average genetic merit of the sows for growth and carcass traits. This approach has been tried in France (Legault and Gruand, 1976), where an improvement of 2.6 eggs in ovulation rate in a Large White hyperprolific line was offset by a $69 \%$ increase in embryonic mortality to give no change in size of first litters at birth. However, evidence is now emerging (Legault, Gruand and Bolet, 1981) that the superior ovulation rate of the hyperprolific line may be expressed as a significant increase in litter size when measured in the improved uterine environment either of crossbred or second litter, purebred, hyperprolific sows. In Norway, national Landrace litter records were screened to give founder hyperprolific dams with a phenotypic superiority of 4.0 piglets born alive over their first three litters'(Skjervold, 1979), but no estimate of the genetic gain has yet been published:-

\section{Future developments}

\section{AREAS FOR RESEARCH}

It was shown earlier (Table 26.8) that the available evidence suggests that genetic associations between reproductive performance and growth and carcass traits are weak. Continued intense selection from traits of the growing pig is not therefore expected to lead to substantial changes in reproductive rate. However, the studies were rather inconclusive and data were collected over 10 years ago, so genetic trends in reproduction should continue to be monitored in national populations. Ideally, proper experiments should be designed and set up to measure the correlated responses in reproductive and fitness traits resulting from direct selection for growth and carcass traits. Such experiments would be large and expensive but 
could, perhaps, be combined with planned or existing selection studies on growth and efficiency. In their absence, the maintenance of unselected control populations (e.g. Smith, 1977) should give warning of any adverse trends in reproductive traits.

One of the consequences of present selection programmes may be an increase in the mature size of the sow, as a result of the reduction in the age and fatness of pigs at a fixed slaughter weight. In turn this could have the effect of increasing sow food costs and possibly raising age at sexual maturity. Other reproductive traits such as length of productive life, ease of mating, conception rate and teat number could also be influenced. In a selection programme for growth, it could be possible to select unintentionally for high or low litter size if maternal effects were not properly eliminated, for example if pigs in smaller litters grew faster. Recent evidence has come to light of small negative selection pressures being applied to litter size in some British nucleus populations (Guy and Steane, 1978), and of selection differentials below the values expected from natural selection in Norwegian Landrance nucleus herds (Skjervold, 1979).

Although selection for improved litter size would have been expected to produce only a slow improvement in the past, two new techniques which could lead to faster rates of improvement will deserve further investigation. The first, simple standardization of litter size to, say, eight pigs/litter, would remove the possible negative maternal correlation between successive generations, and therefore increase the heritability. At present it is unclear just how much the heritability would be expected to increase and, although selection experiments using the technique are under way in American breeds, it will be important that they are repeated in European breeds and under management conditions with larger average litter sizes.

The second new technique deserving continued attention will be the measurement of ovulation rate by laparoscopy. Genetic changes in ovulation rate have so far been accompanied by very small changes in litter size, presumably as a result of the large negative correlation between ovulation rate and embryonic survival. The realized genetic association has been observed mainly in first parity purebred gilts, however, and it is at least possible that improvements in ovulation rate may be better able to be expressed as extra piglets in the improved uterine environment either of a crossbred or of a second or later parity purebred sow (Legault, Gruand and Bolet, 1981). If this is so then selection on some combination of ovulation rate and litter size could prove to be more efficient than selection on litter size alone. In any case further investigation of the genetics and physiology of embryonic survival as the limiting factor would seem to be indicated. In particular, it would be useful to find some method of predicting genetic potential for embryo survival, either soon after first mating or preferably even before puberty.

One of the most neglected aspects of genetic improvement in reproductive potential has been the value of the crossbred boar in libido and semen quality, as affecting conception rates and litter sizes of his mates. A switch to crossbred rather than purebred boars would be an operationally simple, though costly step, and experiments are needed to show whether sufficient heterosis exists in male reproductive characteristics to make this worthwhile. Another subject for investigation will be the inheritance of freeza- 
bility of boar semen, since the semen from roughly $25 \%$ of British boars cannot be frozen (H.C.B. Reed, personal communication). In storing frozen semen for experimental or commercial purposes, any adverse association between freezability and any other aspect of performance would be highly undesirable.

Comparisons of the performance of reciprocal crosses (Johnson, Omtvedt and Walters, 1973) and of gilts reared in litters of different sizes (Nelson and Robison, 1976) have shown that the 'maternal environment' can influence growth, carcass and reproductive traits. The control of the maternal environment through genetic, nutritional or managemental measures could therefore greatly affect the profitability of pig production in the future. New techniques such as ovum transplantation should allow, for example, separation of effects resulting from the pre- and postnatal environments, and a further understanding of the factors which can influence subsequent lifetime performance.

\section{SELECTION PROGRAMMES}

How much emphasis should practical pig breeders place on reproductive performance in present and future genetic improvement programmes? The answer to this question depends on the relative economic benefits of improvement in reproductive versus growth and carcass traits, and on the methods available for predicting an individual pig's genetic potential for reproduction. For the present, selection for reproductive performance would not be justified in terminal sire breeds, since their reproductive rate has little influence on total profitability. Any selection should be confined to the breeds used as constituents of the dam of the slaughter generation, and the emphasis given to reproduction can be greater in these breeds if a terminal sire breed is used than if a backcrossing scheme is used. With present economic values and low heritabilities for litter productivity, there are only small benefits from inclusion of reproduction in a selection index, particularly for the European Large White and Landrace breeds in which litter sizes are already relatively high. More selection for reproduction is justified in the USA where average litter sizes appear to be lower (Table 26.1), and feed costs and carcass grading differentials are lower (Clarke and Smith, 1979).

In the future, as pigs become leaner and variation in fat declines, the relative economic value of a genetic change in all aspects of reproduction will increase. There are already indications that the fat cover on entire male carcasses is approaching an optimum for some processing requirements. In addition, the relative value of an extra live piglet at birth might be greatly increased by the introduction of successful artificial rearing systems. Similarly the relative importance of libido in both sexes might be increased by the need to save labour at mating. The new methods now being investigated for improvement of litter size, such as standardization of litter size at birth or direct measurement of ovulation rate, could raise the effective heritability of the trait to the point where selection would be worthwhile even at present economic values.

It therefore seems likely that the importance of reproduction in genetic 
improvement programmes will increase in the medium or long term. If so, the challenge to find inexpensive and accurate methods of predicting reproductive potential in the young pig will be greater than ever.

\section{References}

ANDRESEN, E. (1979). Evidence indicating the sequence Phi, $\mathrm{Hal}, \mathrm{H}$ of three closely linked loci in pigs. Nord. VetMed. 31, 443-444

BAKKER, H., WALLINGA, J.H. and POLITIEK, R.D. (1976). Reproduction and body weight of mice after longterm selection for litter size. Proc. 27th Ann. Mtg. EAAP, Zurich

BATEMAN, N. (1966). Ovulation and post-ovulational losses in strains of mice selected from large and small litters. Genet. Res. 8, 229-241

BERESKIN, B., SHELBY, C.E. and COX, D.F. (1973). Some factors affecting pig survival. J. Anim. Sci. 36, 321-327

BRADFORD, G.E. (1979). Genetic variation in prenatal survival and litter size. J. Anim. Sci. 49, Supp. II, 66-74

BRASCAMP, E.W. and BUITING, G.A.J. (1980). Preliminary results of Duroc as maternal grandsire of fattening pigs. Proc. 31st Ann. Mtg. EAAP, Munich

BRASCAMP, E.W., COP, W.A.G. and BUITING, G.A.J. (1979). Evaluation of six lines of pigs for crossing. 1. Reproduction and fattening in pure breeding. Z. Tierzücht. ZüchtBiol. 96, 160-169

CLARKE, P.K. and SMITH, C. (1979). The value of litter size as an objective. Proc. European Pig Testing Conf., Harrogate

CUNNINGHAM, P.J., ENGLAND, M.E., YOUNG, L.D. and ZIMMERMAN, D.R. (1979). Selection for ovulation rate in swine : correlated response in litter size and weight. J. Anim. Sci. 48, 509-516

EIKJE, E.D. (1973). [Phenotypic and genetic parameters for litter size in pigs]. Meld. Norg. LandbrHøgsk. 53 (38), 23pp

EISEN, E.J. (1978). Single trait and antagonistic index selection for litter size and body weight in mice. Genetics 88, 781-811

FALCONER, D.S. (1960a). Introduction to Quantitative Genetics. Edinburgh, Oliver and Boyd

FALCONER, D.S. (1960b). The genetics of litter size in mice. J. cell. comp. Physiol. 56, 153-167

FALCONER, D.S. (1973). Replicated selection for body weight in mice. Genet. Res. 22, 291-321

GUY, D.R. and STEANE, D.E. (1978). Correlated selection differential for litter size in Meat and Livestock Commission Pig Improvement Scheme herds. Anim. Prod. 26, 372 (Abstract)

HANSET, R. (1973). [Inbreeding and relationships in the Pietrain pig]. Ann. Génét. Sél. Anim. 5, 177-188

HETZER, H.O. and MILLER, R.H. (1970). Influence of selection for high and low fatness on reproductive performance of swine. J. Anim. Sci. 30, $481-495$

HUTCHENS, L.K., JOHNSON, R.K., WELTY, S.D. and SCHOOLEY, J. (1978). Age and weight at puberty for purebred and crossbred gilts of four breeds. Rep. Okla. agric. Exp. Stn. MP-103, 126-130 
IMLAH, P. (1970). Evidence for the $T_{f}$ locus being associated with an early lethal factor in a strain of pigs. Anim. Bld. Grp. Biochem. Genet. 1, 5-13

ISLAM, A.B.M.M., HILL, W.G. and LAND, R.B. (1976). Ovulation rate in lines of mice selected for testis weight. Genet. Res. 27, 23-32

JOAKIMSEN, $\emptyset$. and BAKER, R.L. (1977). Selection for litter size in mice. Acta Agric. scand. 27, 301-318

JOHNSON, R.K., OMTVEDT, I.T. and WALTERS, L.E. (1973). Evaluation of purebreds and two breed crosses in swine : feedlot performance and carcase merit J. Anim. Sci. 37, 18-26

JOHNSON, R.K., OMTVEDT, I.T. and WALTERS, L.E. (1978). Comparison of productivity and performance for two-breed and three-breed crosses in swine. J. Anim. Sci. 46, 69-82

JONSSON, P. (1971). Population parameter estimates of the Danish Landrace pig. Acta Agric. scand. 21, 11-16

KING, J.W.B. (1967). Pig breeding research. Proc. 9th Int. Congr. Anim. Prod., Edinburgh, pp. 9-16. Edinburgh, Oliver and Boyd

KING, J.W.B. (1975). Retarded growth in Hampshire piglets. Livestock Prod. Sci. 2, 69-77

KING, J.W.B. (1978). Alternative crossing systems for pigs. ABRO Report 1978, pp. 15-18. London, Agricultural Research Council

KING, J.W.B. and THORPE, W. (1973). Experiments with Pietrain/Hampshire crossbred boars. Proc. 24th Ann. Mig. EAAP, Vienna

LAND, R.B. (1973). The expression of female, sex-limited characters in the male. Nature (Lond.) 241, 208-209

LAND, R.B. and FALCONER, D.S. (1969). Genetic studies of ovulation rate in the mouse. Genet. Res. 13, 25-46

LANGHOLZ, H.-J. (1968). [Inbreeding and relationships in Norwegian Landrace pigs]. Meld. Norg. LandbrHøisk. 47, (2), 10pp

LEGAULT, C. (1970). [Statistical and genetical study of the performance of Large White sows. II. Direct effect of the boar, heritability, repeatability, correlations]. Ann. Génét. Sél. Anim. 2, 209-227

LEGAULT, C. (1971). [Relationship between reproductive performance and fattening and carcase characters in the pig]. Ann. Génét. Sél. Anim. 3, $153-160$

LEGAULT, C. and GRUAND, J. (1976). [Improvement of the reproductive performance of sows by creation of a "hyperprolific" line and use of artificial insemination : principle and preliminary results]. Journées de la recherche porcine en France, pp. 201-206. Paris, L'Institut Technique du Porc

LEGAULT, C., GRUAND, J. and BOLET, G. (1981). [Results from the purebred and crossbred use of a "hyperprolific" line]. Journées de la recherche porcine en France, pp. 255-260. Paris, L'Institut Technique du Porc

LISHMAN, W.B., SMITH, W.C., BICHARD, M. and THOMPSON, R. (1975). The comparative performance of purebred and crossbred boars in commercial pig production. Anim. Prod. 21, 69-75

LOPEZ-FANJUL, C. (1974). Selection from crossbred populations. Anim. Breed. Abstr. 42, 403-416

LUSH, J.L. and ANDERSON, A.L. (1939). A genetic history of Poland China swine. II. Founders of the breed, prominent individuals, length of generation. J. Hered. 30, 219-224 
MARTIN, P.A. and DZIUK, P.J. (1977). Assessment of relative fertility of males (cockerels and boars) by competitive mating. J. Reprod. Fert. 49, 323-329

MIKAMI, H., FREDEEN, H.T. and SATHER, A.P. (1977). Mass selection in a pig population. 2. The effects of inbreeding within the selected populations. Can. J. Anim. Sci. 57, 627-634

MOAV, R. (1966). Specialised sire and dam lines. I. Economic evaluation of crossbreds. Anim. Prod. 8, 193-202

MOAV, R. and HILL, W.G. (1966). Specialised sire and dam lines. IV. Selection within lines. Anim. Prod. 8, 375-390

MORRIS, C.A. (1975). Genetic relationships of reproduction with growth and with carcase traits in British pigs. Anim. Prod. 20, 31-44

NEELY, J.D., JOHNSON, B.H. and ROBISON, O.W. (1980). Heterosis estimates for measures of reproductive traits in crossbred boars. J. Anim. Sci. 51, 1070-1077

NELSON, R.E. and ROBISON, O.W. (1976). Effects of postnatal maternal environment on reproduction of gilts. J. Anim. Sci. 43, 71-77

OLLIVIER, L. and BOLET, G. (1981). [Selection for prolificacy in the pig : results after ten generations of selection]. Journées de la recherche porcine en France, pp. 261-268. Paris, L'Institut Technique du Porc

QUINTANA, F.G. (1979). Crossbreeding in swine, an evaluation of systems. PhD Thesis. North Carolina State University

RASMUSEN, B.A. and HAGEN, K.L. (1973). The H blood-group system and reproduction in pigs. J. Anim. Sci. 37, 568-573

REVELLE, T.J. and ROBISON, O.W. (1973). An explanation for the low heritability of litter size in swine. J. Anim. Sci. 37, 668-675

RUTLEDGE, J.J. (1980). Fraternity size and swine reproduction. 1. Effect on fecundity of gilts. J. Anim. Sci. 51, 868-870

SCHNEIDER, A., SCHMIDLIN, J. and GERWIG, C. (1980). Investigation of reproductive performances of purebred and crossbred sows of a pig production organisation. Proc. 31st Ann. Mtg. EAAP, Munich

SELLIER, P. (1970). [Heterosis and crossbreeding in swine]. Ann. Génét. Sél. Anim. 2, 145-207

SELLIER, P. (1976). The basis of crossbreeding in pigs; a review. Livestock Prod. Sci. 3, 203-226

SHERIDAN, A.K. (1981). Crossbreeding and heterosis. Anim. Breed. Abstr. 49, 131-144

SKJERVOLD, H. (1979). What about the genetic improvement of litter size? Acta Agric. scand. Supplement 21, 176-184

SMITH, C. (1964). The use of specialised sire and dam lines in selection for meat production. Anim. Prod. 6, 337-344

SMITH, C. (1977). Use of stored frozen semen and embryos to measure genetic trends in farm livestock. Z. Tierzücht ZuchtBiol. 94, 119-127

SMITH, C., JORDAN, C.H.C., STEANE, D.E. and SWEENEY, M.B. (1978). A note on inbreeding and genetic relationships among British tested pigs. Anim. Prod. 27, 125-128

SMITH, C. and WEBB, A.J. (1980). Effects of major genes on animal breeding strategies. Proc. 3lst Ann. Mtg. EAAP, Munich

STRANG, G.S. (1970). Litter productivity in Large White pigs. 1. The relative importance of some sources of variation. Anim. Prod. 12, 225-233 


\section{Genetics of reproduction in the pig}

STRANG, G.S. and KING, J.W.B. (1970). Litter productivity in Large White pigs. 2. Heritability and repeatability estimates. Anim. Prod. 12, 235243

STRANG, G.S. and SMITH, C. (1979). A note on the heritability of litter traits in pigs. Anim. Prod. 28, 403-406

VANGEN, O. (1980). Studies on a two trait selection experiment in pigs. VI. Heritability estimates of reproductive traits. Influence of maternal effects. Acta Agric. scand. 30, 320-326

weBb, A.J. (1981). The halothane sensitivity test. Proc. Symp. Porcine Stress and Meat Quality, Moss, Norway, pp. 105-124. As, Norwegian Agricultural Food Research Society

WILSON, E.R. and JOHNSON, R.K. (1979). A comparison of mating systems utilizing Duroc, Hampshire and Yorkshire breeds for swine production. Rep. Okla. agric. Exp. Sin. MP-104, 178-183

WILSON, E.R., JOHNSON, R.K. and WETTEMAN, R.P. (1977). Reproductive and testicular characteristics of purebred and crossbred boars. J. Anim. Sci. 44, 939-947

YOUNG, L.D., JOHNSON, R.K. and OMTVEDT, I.T. (1976). Reproductive performance of swine bred to produce purebred and two-breed cross litters. J. Anim. Sci. 42, 1133-1149 